\title{
Trace Elements Content of Some Traditional Plants Used for the Treatment of Diabetes Mellitus
}

\author{
Ahmad Gholamhoseinian 1,2 (iD), Beydolah Shahouzehi ${ }^{3}$ * (D), Gholamabbas Mohammadi 1,2 (D) \\ 1 Department of Clinical Biochemistry, Kerman University of Medical Sciences, Kerman, Iran \\ 2 Physiology Research Center, Institute of Basic and Clinical Physiology Sciences, Kerman University of Medical Sciences, \\ Kerman, Iran \\ 3 Cardiovascular Research Center, Institute of Basic and Clinical Physiology Sciences, Kerman University of Medical \\ Sciences, Kerman, Iran \\ * Correspondence: b.shahozehi@kmu.ac.ir; bshahouzehi@gmail.com;
}

Scopus Author ID 36470992900

Received: 23.04.2020; Revised: 7.05.2020; Accepted: 9.05.2020; Published: 12.05.2020

\begin{abstract}
Diabetes is a public health problem that affects life quality. Trace elements have a critical role in the activity and structure of the enzymes involve in carbohydrate metabolism. Many traditional herbs have been used for the treatment and management of Diabetes Mellitus (DM). Anti-diabetic medicinal plants have a significant lowering effect on blood sugar, then assessment of mineral content of these plants has a great value to judge their mechanism of action. Determination of Cobalt $(\mathrm{Co})$, Chromium (Cr), Ferrum (Fe), Manganese (Mn), Molybdenum (Mo), Selenium (Se), Vanadium (V), and Zinc $(\mathrm{Zn})$ values in twenty-eight anti-diabetic plants were conducted and the estimation carried out by atomic absorption spectrophotometry after wet digestion. We found that the levels of Mn, Mo, Co, and $\mathrm{Cr}$ were in trace amount, whereas $\mathrm{Fe}, \mathrm{Se}, \mathrm{V}$ and $\mathrm{Zn}$ contents were higher. Because of trace elements variations between the studied plants, the hypoglycemic effect of these herbs is not due to a unique element present in the herbs, it rather a synergic effect of several elements might account for the hypoglycemic nature of these plants. Further work is necessary to evaluate this phenomenon.
\end{abstract}

Keywords: Trace elements; Diabetes mellitus; Anti-diabetic plants; Selenium; Vanadium.

(C) 2020 by the authors. This article is an open access article distributed under the terms and conditions of the Creative Commons Attribution (CC BY) license (https://creativecommons.org/licenses/by/4.0/).

\section{Introduction}

Diabetes mellitus (DM) is a public health problem and characterized as a chronic metabolic disease that has a serious effect on the life expectancy and quality in the patients, also DM treatment is a global problem. DM has some secondary long time effects that deteriorating the patient's condition including retinopathy, kidney disorder, and cardiac effects $[1,2]$. Medicinal plants showed several beneficial effects over wide range diseases and the researchers focus on the medicinal plants properties to find new, safe and potent agents to improve and/or cure diseases including DM [1,3-6]. Traditional and medicinal plants are widely used around the world as a treatment for DM and several studies have proved antidiabetic effect of many species of plants such as: Cressa cretica L. [7], Trigonella-foenum graecum, Syzygium jambolona, panax ginseng [8], Morus alba Linn [9], Allium cepa [10], Cinnamomum zeylanicum, Cinnamomum cassia [11], Melina azadiracta [12], Coriandrum sativum [13], Rosa damascene, and Quercus infectoria [5].

Trace elements are necessary and essential for good health [2,7]. Trace elements and some metals serve as cofactors in many enzymatic reactions; they also have some critical roles in the physiological processes in the body including carbohydrate homeostasis and metabolism. 
Any abnormalities in essential metabolic elements can cause dysfunction and disorder $[3,14]$. Trace elements have been identified as potential candidates for some metabolic dysfunction such as DM, insulin resistance, obesity, and metabolic syndrome [3,4,7,10]. It reported that some trace elements deficiencies can promote DM complications and also there reports that proved that some trace elements were reduced in patients with DM [7,14-17]. Several studies have been proved that there is a relationship between the development of DM and some trace elements levels. The most important trace elements that related to the DM are Chromium $(\mathrm{Cr})$, Zinc (Zn), Selenium (Se), and Vanadium (V) [16-18,20].

$\mathrm{Cr}$ is related to glucose metabolism and is important for normal glucose homeostasis and involved in insulin action as a part of GTF (Glucose tolerance factor). Cr deficiency is characterized by hyperglycemia, impaired glucose tolerance, and lipid disorders [16-19, 21]. $\mathrm{Zn}$ is correlated with insulin biosynthesis and secretion from pancreas $\beta$-cells $[3,16]$. Zn plays a pivotal role in the stabilization of insulin hexamer and insulin storage in the pancreas and increases insulin concentrations in both types of DM (type 1 and 2). On the other hand, Zn also acts as an efficient antioxidant and defends the cells against free radicals $[3,17,20]$. Se reduction was reported in DM $[3,16]$. $\mathrm{V}$ also possesses anti-diabetic properties and described as an insulin-mimetic element $[14,16,18]$.

Trace element contents of anti-diabetic plants are variable. Narendhirakannan and colleagues studied the elemental composition of four traditional medicinal plants. They found that various trace elements such as $\mathrm{V}, \mathrm{Zn}, \mathrm{Cr}$, and Nickel (Ni) can be counted for hypoglycemic effect of those plants [10,22]. Mineral contents of some different species of the genus Ficus Linn that have anti-diabetic properties were conducted by atomic absorption spectrophotometry. The results showed that these species of Ficus genus are a good source of required elements for patients and they contain some specific trace elements that can improve insulin action [1].

Currently available therapeutic options for DM such as dietary change, taking oral hypoglycemic agents, and insulin therapy have shown to have their own limitations. Many natural products and herbal medicines have been recommended for the treatment of DM [23]. In Iran, some traditional plants have been consumed by diabetic people to reduce their health problems but their involved active agents are not well known. Probably trace elements can be considered as responsible for these plants' pharmacological effects. For this reason, some plants commonly consumed to reduce blood glucose were analyzed for their trace element contents using atomic absorption spectrophotometry.

\section{Materials and Methods}

Medicinal plants were purchased from the medicinal herbal markets in Kerman city and all of them were botanically identified and a voucher specimen of each plant was deposited at the herbarium of the Herbal Medicine Research Center Faculty of Pharmacy, Kerman University of Medical Sciences, Iran (Table 1). About $0.5 \mathrm{gr}$ of the dried and grounded plant samples were digested in nitric acid overnight at room temperature. Then samples heated for 4 hours. The digested samples were cooled and dissolved in $50 \mathrm{~mL}$ of deionized water and were used for the assay of trace elements through atomic absorption Spectrophotometry. The standard curve of each element was obtained by dilution of stock solutions [24,25].

A Varian flameless atomic absorption spectrophotometer, model 220 AA, equipped with a Varian graphite furnace and auto sampling system were used in all determinations. As the light source, a hollow cathode lamp from Varian was used and pyrolytic coated graphite 
tubes was utilized as atomizer. The conditions for analysis were based on the instructions presented by the instrument manual. Samples of $25 \mu \mathrm{L}$ were carried to the graphite tube by the auto sampling system and submitted to the furnace established conditions.

\section{Results and Discussion}

The concentration of elements analysed in this study was ordered and showed in table 1 , and mineral contents of the anti-diabetic plants presented in table 2.

Interestingly, Allium sativum showed maximum content of Vanadium (V). In five other plants Selenium (Se) was leading trace elements regarding content that they are including: Apium graveolens, Cannabis sativa, Juniperus communis, Teucrium polium and Zataria multiflora. Fe content of the rest of plants was higher than other elements. The orders of Ferrum $(\mathrm{Fe})>\mathrm{Se}>\mathrm{Zinc}(\mathrm{Zn})>$ and $\mathrm{Fe}>\mathrm{Se}>\mathrm{Zn}>\mathrm{V}$ were more frequent in plants of our study. Minimum and maximum of minerals in studied plants are showed in table 3.

Table 1. Families, Species, used parts and profile of concentration ordered elements in the anti-diabetic plants.

\begin{tabular}{|c|c|c|c|}
\hline Species & Family & Utilized part & Profile of elements conc. \\
\hline Allium cepa & Alliaceae & Bark & $\mathrm{Fe}>\mathrm{Zn}>\mathrm{V}>\mathrm{Se}>\mathrm{Mo}>\mathrm{Co}>\mathrm{Cr}>\mathrm{Mn}$ \\
\hline Allium Sativum & Amaryllidaceae & Fruit & $\mathrm{V}>\mathrm{Fe}>\mathrm{Se}>\mathrm{Zn}>\mathrm{Mo}>\mathrm{Co}>\mathrm{Cr}>\mathrm{Mn}$ \\
\hline Apium graveolens & Umbelliferae & leaves & $\mathrm{Se}>\mathrm{Fe}>\mathrm{Zn}>\mathrm{Co}>\mathrm{V}>\mathrm{Mo}>\mathrm{Mn}>\mathrm{Cr}$ \\
\hline Actium lappa & Asteraceae & Root & $\mathrm{Fe}>\mathrm{Zn}>\mathrm{V}>\mathrm{Se}>\mathrm{Mo}>\mathrm{Co}>\mathrm{Cr}>\mathrm{Mn}$ \\
\hline Cannabis sativa & Cannabaceae & Seed & $\mathrm{Se}>\mathrm{Zn}>\mathrm{Fe}>\mathrm{Mn}>\mathrm{Co}>\mathrm{V}>\mathrm{Cr}>\mathrm{Mo}$ \\
\hline Capparis spinosa & Lauraceae & & $\mathrm{Fe}>\mathrm{V}>\mathrm{Zn}>\mathrm{Se}>\mathrm{Co}>\mathrm{Mo}>\mathrm{Cr}>\mathrm{Mn}$ \\
\hline Cinnamomum zeylanica & Lauraceae & Bark & $\mathrm{Fe}>\mathrm{Mn}>\mathrm{Se}>\mathrm{V}>\mathrm{Zn}>\mathrm{Co}>\mathrm{Mo}>\mathrm{Cr}$ \\
\hline Citrullus colocynthis & Cucurbitaceae & Fruit & $\mathrm{Fe}>\mathrm{Se}>\mathrm{Zn}>\mathrm{V}>\mathrm{Co}>\mathrm{Cr}>\mathrm{Mo}>\mathrm{Mn}$ \\
\hline Coriandrum sativum & Alliaceae & & $\mathrm{Fe}>\mathrm{Se}>\mathrm{Zn}>\mathrm{V}>\mathrm{Mo}>\mathrm{Co}>\mathrm{Cr}>\mathrm{Mn}$ \\
\hline Cucumic sativus & Cucurbitaceae & Bark & $\mathrm{Fe}>\mathrm{V}>\mathrm{Zn}>\mathrm{Se}>\mathrm{Co}>\mathrm{Mo}>\mathrm{Cr}>\mathrm{Mn}$ \\
\hline Cuminum cyminum & Alliaceae & Seed & $\mathrm{Fe}>\mathrm{V}>\mathrm{Se}>\mathrm{Zn}>\mathrm{Co}>\mathrm{Cr}>\mathrm{Mo}>\mathrm{Mn}$ \\
\hline Datura stramonium & Solanaceae & Seed & $\mathrm{Fe}>\mathrm{Se}>\mathrm{Zn}>\mathrm{Co}>\mathrm{V}>\mathrm{Mo}>\mathrm{Cr}>\mathrm{Mn}$ \\
\hline Ficus carica & Moraceae & Leaves & $\mathrm{Fe}>\mathrm{Se}>\mathrm{V}>\mathrm{Zn}>\mathrm{Mo}>\mathrm{Co}>\mathrm{Cr}>\mathrm{Mn}$ \\
\hline Fumaria parviflora & Fumariaceae & Arial part & $\mathrm{Fe}>\mathrm{Se}>\mathrm{V}>\mathrm{Zn}>\mathrm{Mo}>\mathrm{Mn}>\mathrm{Cr}>\mathrm{Co}$ \\
\hline Glycyrrhiza glabra & Fabaceae & Root & $\mathrm{Fe}>\mathrm{Se}>\mathrm{Zn}>\mathrm{V}>\mathrm{Mo}>\mathrm{Co}>\mathrm{Cr}>\mathrm{Mn}$ \\
\hline Juglans regia & Juglandaceae & Leaves & $\mathrm{Fe}>\mathrm{Se}>\mathrm{Zn}>\mathrm{Mn}>\mathrm{V}>\mathrm{Co}>\mathrm{Cr}>\mathrm{Mo}$ \\
\hline Juniperus communis & Cupressaceae & Flower & $\mathrm{Se}>\mathrm{Fe}>\mathrm{V}>\mathrm{Zn}>\mathrm{Mn}>\mathrm{Co}>\mathrm{Cr}>\mathrm{Mo}$ \\
\hline Lactuca sativa & Asteraceae & Leave & $\mathrm{Fe}>\mathrm{Se}>\mathrm{Zn}>\mathrm{Co}>\mathrm{V}>\mathrm{Mo}>\mathrm{Mn}>\mathrm{Cr}$ \\
\hline Morus alba & Moraceae & Leave & $\mathrm{Fe}>\mathrm{Se}>\mathrm{V}>\mathrm{Zn}>\mathrm{Mn}>\mathrm{Co}>\mathrm{Cr}>\mathrm{Mo}$ \\
\hline Plantago psyllium & Plantaginaceae & & $\mathrm{Fe}>\mathrm{Zn}>\mathrm{Se}>\mathrm{V}>\mathrm{Co}>\mathrm{Mo}>\mathrm{Mn}>\mathrm{Cr}$ \\
\hline Punica granatum & Lythraceae & Bark & $\mathrm{Fe}>\mathrm{Se}>\mathrm{V}>\mathrm{Zn}>\mathrm{Co}>\mathrm{Mo}>\mathrm{Cr}>\mathrm{Mn}$ \\
\hline Sesamum indicum & Pedaliaceae & Seed & $\mathrm{Fe}>\mathrm{Se}>\mathrm{Zn}>\mathrm{V}>\mathrm{Co}>\mathrm{Mo}>\mathrm{Cr}>\mathrm{Mn}$ \\
\hline Spinacia oleracea & Chenopodiaceae & Leave & $\mathrm{Fe}>\mathrm{V}>\mathrm{Se}>\mathrm{Zn}>\mathrm{Mn}>\mathrm{Co}>\mathrm{Cr}>\mathrm{Mo}$ \\
\hline Teucrium polium & Lamiaceae & Arial parts & $\mathrm{Se}>\mathrm{Fe}>\mathrm{Zn}>\mathrm{Mo}>\mathrm{V}>\mathrm{Co}>\mathrm{Cr}>\mathrm{Mn}$ \\
\hline Trigonella foenum-graecum & Fabaceae & Seed & $\mathrm{Fe}>\mathrm{Se}>\mathrm{Zn}>\mathrm{V}>\mathrm{Mo}>\mathrm{Cr}>\mathrm{Co}>\mathrm{Mn}$ \\
\hline Urtica urens & Uricaceae & Arial pars & $\mathrm{Fe}>\mathrm{Se}>\mathrm{Zn}>\mathrm{V}>\mathrm{Co}>\mathrm{Cr}>\mathrm{Mn}>\mathrm{Mo}$ \\
\hline Vaccinium arctostaphylos & Ericaceae & Fruit & $\mathrm{Fe}>\mathrm{Se}>\mathrm{Zn}>\mathrm{Mn}>\mathrm{V}>\mathrm{Co}>\mathrm{Cr}>\mathrm{Mo}$ \\
\hline Zataria multiflora & Lamiaceae & Arial paarts & $\mathrm{Se}>\mathrm{V}>\mathrm{Zn}>\mathrm{Fe}>\mathrm{Cr}>\mathrm{Mo}>\mathrm{Mn}>\mathrm{Co}$ \\
\hline
\end{tabular}

Trace elements have been characterized for a long time as anti-diabetic agents. They are involved in metabolism and enzymatic reactions in the body [3,16]. In this study, we showed elemental contents of some traditional plants which is used as an anti-diabetic sources. We assessed elements that their anti-diabetic properties have already been shown including $\mathrm{Cr}$, Cobalt (Co), Fe, Manganese (Mn), Molybdenum (Mo), Se, V and Zn [3,8]. In one out of 28 plants $\mathrm{V}$ content was maximum, and in five out of $28 \mathrm{Se}$ content were maximum and in the rest of plants, $\mathrm{Fe}$ was the main element. Zucchi et al. assessed many elements concentration including trace elements we used in this study, in eight hypoglycemic plants [8]. They reported that in some of these plants trace elements like $\mathrm{Se}, \mathrm{Cr}$ and $\mathrm{V}$ were not detected, and this report is challenging this fact that these elements have hypoglycemic effects. They also have reported that $\mathrm{Cr}$, Mo, Se and V were not detected in Trigonella foenum graecum, a potent anti-diabetic 
plant, which is totally in contrast with our results. On the other hand, they showed the order of $\mathrm{Fe}>\mathrm{Mn}>\mathrm{Zn}>\mathrm{Co}$ for other detected elements [8] and we showed this order: $\mathrm{Fe}>\mathrm{Se}>\mathrm{Zn}>\mathrm{V}>$ $\mathrm{Mo}>\mathrm{Cr}>\mathrm{Co}>\mathrm{Mn}$.

Table 2. Trace elements concentration of plants ( $\mu \mathrm{g} / \mathrm{g}$ dry wt).

\begin{tabular}{l|l|l|l|l|l|l|l|l} 
Plants & Co & Cr & Fe & Mn & Mo & Se & V & Zn \\
\hline Allium cepa & 1.309 & 0.515 & 19.45 & 0.12 & 1.915 & 2.4 & 4.03 & 4.221 \\
\hline Allium Sativum & 0.911 & 0.476 & 6.1 & 0.12 & 1.12 & 4.0 & 10.36 & 2,868 \\
\hline Apium graveolens & 1.346 & 0.597 & 6.04 & 0.64 & 1.112 & 7.9 & 1.28 & 4.706 \\
\hline Arctium lappa & 1.365 & 0.548 & 16.23 & 0.25 & 1.818 & 3.1 & 5.12 & 5.215 \\
\hline Cannabis sativa & 1.408 & 0.665 & 22.09 & 1.57 & 0.032 & 9.4 & 1.27 & 5.741 \\
\hline Capparis spinosa & 1.35 & 0.497 & 18.63 & 0.01 & 0.615 & 2.4 & 5.2 & 4.388 \\
\hline Cinnamomum zeylanica & 1.023 & 0.835 & 11.68 & 5.27 & 0.99 & 4.6 & 4.34 & 2.693 \\
\hline Citrullus colocynthis & 0.9 & 0.425 & 11.89 & 0.03 & 0.195 & 8.0 & 3.61 & 3.945 \\
\hline Coriandrum sativum & 0.899 & 0.788 & 22.09 & 0.52 & 0.915 & 13.1 & 1.58 & 3.695 \\
\hline Cucumic sativus & 1.222 & 0.487 & 24.89 & 0.28 & 0.717 & 2.4 & 5.2 & 3.776 \\
\hline Cuminum cyminum & 1.00 & 0.835 & 33.39 & 0.48 & 0.815 & 5.2 & 7.95 & 4.074 \\
\hline Datura stramonium & 1.27 & 0.346 & 36.84 & 0.16 & 0.412 & 9.7 & 1.27 & 3.997 \\
\hline Ficus carica & 1.42 & 0.785 & 10.07 & 0.11 & 2.001 & 5.2 & 4.62 & 2.926 \\
\hline Fumaria parviflora & 0.147 & 1.104 & 20.39 & 1.19 & 2.04 & 7.9 & 5.14 & 3.447 \\
\hline Glycyrrhiza glabra & 0.911 & 0.266 & 22.45 & 0.17 & 1.0 & 5.3 & 1.29 & 3.407 \\
\hline Juglans regia & 1.281 & 1.108 & 43.02 & 2.63 & 0.037 & 14.0 & 1.43 & 3.716 \\
\hline Juniperus communis & 0.983 & 0.857 & 12.79 & 1.01 & 0.817 & 27.0 & 5.98 & 3.588 \\
\hline Lactuca sativa & 1.471 & 0.335 & 8.41 & 0.86 & 1.018 & 6.5 & 1.36 & 3.7 \\
\hline Morus alba & 1.553 & 1.205 & 7.24 & 1.76 & 0.989 & 5.2 & 4.99 & 3.151 \\
\hline Plantago psyllium & 1.281 & 0.09 & 11.52 & 0.72 & 1.111 & 4.3 & 4.03 & 6.227 \\
\hline Punica granatum & 1.391 & 0.879 & 24.87 & 0.19 & 1.115 & 5.8 & 5.64 & 3.225 \\
\hline Sesamum indicum & 1.156 & 0.634 & 30.92 & 0.23 & 1.145 & 14 & 1.39 & 5.338 \\
\hline Spinacia oleracea & 1.427 & 1.022 & 21.1 & 2.62 & 1.008 & 5.2 & 5.51 & 3.834 \\
\hline Teucrium polium & 1.264 & 0.905 & 5.87 & 0.74 & 3.001 & 13 & 1.3 & 5.278 \\
\hline Trigonella foenum-graecum & 0.852 & 0.93 & 9.65 & 0.75 & 1.18 & 7.9 & 1.7 & 3.691 \\
\hline Urtica urens & 1.329 & 1.156 & 13.27 & 0.24 & 0.038 & 13 & 1.53 & 3.184 \\
\hline Vaccinium arctostaphylos & 0.718 & 0.159 & 13.9 & 1.23 & 0.095 & 5.7 & 1.22 & 5.361 \\
\hline Zataria multiflora & 0.766 & 1.039 & 2.53 & 0.91 & 1.008 & 5.8 & 5.17 & 3.703
\end{tabular}

Table 3. Minimum and maximum of minerals in studied plants.

\begin{tabular}{l|l|l} 
Element & Min & Max \\
\hline $\mathbf{C o}$ & Fumaria parviflora & Morus alba \\
\hline $\mathbf{C r}$ & Plantago psyllium & Morus alba \\
\hline $\mathbf{F e}$ & Zataria multiflora & Juglans regia \\
\hline $\mathbf{M n}$ & Capparis spinosa & Cinnamomum zeylanica \\
\hline $\mathbf{M o}$ & Cannabis sativa & Teucrium polium \\
\hline $\mathbf{S e}$ & Allium cepa, Cucumic sativus, Capparis spinosa & Juniperus communis \\
\hline $\mathbf{V}$ & Vaccinium arctostaphylos & Allium sativum \\
\hline $\mathbf{Z n}$ & Cinnamomum zeylanica & Plantago psyllium
\end{tabular}

Narendhirakannan and colleagues also investigated the mineral contents of four medicinal plants used in the treatment of diabetes by AAS analysis. They investigated $\mathrm{Cr}, \mathrm{Zn}$, $\mathrm{V}$, and $\mathrm{Fe}$. The elements profile of four plants showed that $\mathrm{Fe}$ was maximum and $\mathrm{Zn}$ was minimum between these four elements. This profile is almost different from the profile that we showed in table 1 . The average of $\mathrm{Cr}$ contents in our study was lower, and on the other hand, the average of $\mathrm{Fe}, \mathrm{Zn}$ and $\mathrm{V}$ contents of our plants were higher than Narendhirakannan and coworkers study [22].

Investigations support this fact that deficiency of some trace elements in diabetic patients plays a great role in the development of diabetes mellitus $[3,17,20]$. Zhou et al (2019) have reported that $\mathrm{Cr}$ levels were reduced in patients with type $2 \mathrm{DM}$ [18]. Ahmed et al (2018) reported that $\mathrm{Cr}, \mathrm{Zn}$ and $\mathrm{Mg}$ significantly reduced in people with $\mathrm{DM}$, they also reported that between patients with either type 1 or type 2 of DM there was no difference in trace element profile [14]. Kazi et al (2008) have shown that the mean values of $\mathrm{Cr}, \mathrm{Mn}$ and $\mathrm{Zn}$ were 
significantly reduced in blood samples of diabetic patients and also they showed that the urinary levels of these elements were higher in diabetic patients than the control group [26]. This study proved the pivotal protective role of trace elements against diabetes mellitus. Then the plants which have insulin-mimetic, hypoglycemic and anti-diabetic properties may conduct these properties by helpful effects of trace elements contents. Our anti-diabetic plants showed great content of essential trace elements. Other studies also showed that some of these antidiabetic plants are a good source of essential trace elements $[8,22,10]$.

The contents of $\mathrm{Fe}, \mathrm{Se}, \mathrm{V}$, and $\mathrm{Mn}$ are higher than other elements in the current study, and it seems that these elements are more important than other elements in plants that we studied. Altered iron homeostasis is associated with DM [27]. In twenty-two anti-diabetic plants, Fe content was higher than other elements that point to the important impact of Fe on DM. Se reduction observed in DM and there is an association between Se reduction and increased oxidative stress [3]. Se concentrations in some of the plants including; Juniperus communis, Sesamum indicum and Juglans regia were higher than others that indicate a potential negative association of these plants with DM, also these plants are a candidate as antioxidant resources. Harati et al (2003) showed that administration of a low dose of Vanadyl sulfate can preserve functional characteristics of $\beta$-cells and thereby can be an insulin resistance preventive agent [28]. $\mathrm{V}$ has been known because of its insulin-mimetic and anti-diabetic properties [3,16]. Allium sativum is the only plant in this study that showed a higher concentration of $\mathrm{V}$ than other elements and this supports anti-diabetics properties of Allium sativum [29] and anti-diabetic role of $\mathrm{V}$ that has been proved earlier [28]. Zn plays an important role in the storage and structure of insulin and the association between $\mathrm{Zn}$ deficiency and DM has been documented $[3,16,17,20]$. In many of our studied plants, $\mathrm{Zn}$ was in high concentration and proved that it is an effective ingredient in anti-diabetic plants.

\section{Conclusions}

Finally, in our study 8 elements were determined in 28 anti-diabetic plants. We showed that the concentration of $\mathrm{Fe}, \mathrm{Zn}, \mathrm{Se}$ and $\mathrm{V}$ were in higher than other elements. It seems that hypoglycemic effect of studied plants is not due to a unique element present in the herb. Probably there is a synergic effect of several elements in these plants. Authors suggesting that further study on these plants for their protecting effects against DM regarding elemental content of them are necessary. Also, heavy metal and Mercury content of these plants if exists, should be assessed to be sure that these plants have no toxic effects on human.

\section{Funding}

This research received no external funding.

\section{Acknowledgments}

We would like to appreciate Mr. Mohmmadhassan Beigi's kind helps, also we appreciate Kerman Medical University Research Council for their help and support.

\section{Conflicts of Interest}

The authors declare no conflict of interest. 


\section{References}

1. Yasmin Khan, K.; Khan, M.A.; Niamat, R.; Shah, G.M.; Fazal, H.; Seema, N.; Hussain, I.; Ahmad, I.; Inayat, H.; Jan, G.; Kanwal, F. Elemental content of some anti-diabetic ethomedicinal species of genus Ficus Linn. Using atomic absorption spectrophotometry technique. J. Med. Plants Res. 2012, 6, 2136-2140.

2. Nashiry, M.; Ishak, I.; Mohamed, J.; Budin, S.; Mohd Fairulnizal, M.N.; Kamaralzaman, S.; AL-Mekhlafi, H.M. Evaluation of Trace Elements in Malay Women with Type 2 Diabetes Mellitus. Sains Malaysiana 2019, 48, 337-345. https://doi.org/10.17576/jsm-2019-4802-10.

3. Wiernsperger, N.; Rapin, J.R. Trace elements in glucometabolic disorders: an update. Diabetology and Metabolic Syndrome 2010, 2, 70, https://doi.org/10.1186/1758-5996-2-70.

4. Stupar, J.; Vertovec, M.; Dolinsek, F. Longitudal hair chromium profiles of elderly subjects with normal glucose tolerance and type-2 diabetes mellitus. Metab Clin Exp. 2007, 56, 94-104, https://doi.org/10.1016/j.metabol.2006.09.003.

5. Gholamhoseinian, A.; Shahouzehi, B.; Joukar, S.; Iranpoor, M. Effect of Quercus infectoria and Rosa damascena on lipid profile and atherosclerotic plaque formation in rabbit model of hyperlipidemia. Pak $J$ Biol Sci. 2012, 15, 27-33, https://doi.org/10.3923/pjbs.2012.27.33.

6. Joukar, S.; Askarzadeh, M.; Shahouzehi, B.; Najafipour, H.; Fathpour, H. Assessment of Safety and Therapeutic Efficacy of Rosa damascena L. and Quercus infectoria on Cardiovascular Performance of Normal and Hyperlipidemic Rabbits: Physiologically Based Approach. Journal of Toxicology 2013, https://doi.org/10.1155/2013/769143.

7. Rani, S.; Gahlot, K.; Kumar, A. Experimental evidences of antidiabetic activity of aqueous extract of Cressa cretica L. on streptozotocin induced diabetes in rats. Letters in Applied NanoBioScience 2020, 9, 774-778, https://doi.org/10.33263/LIANBS91.774778.

8. Zucchi, O.L.A.D.; Moreira, S.; De Jesus, E.F.O.; Neto, H.S.; Salvador, M.J. Characterization of hypoglycemiant plants by total reflection X-ray fluorescence spectrometry. Biological Trace Element Research 2005, 103, 277-290, https://doi.org/10.1385/BTER:103:3:277.

9. Hamdy, S.H. Effect of Morus alba Linn extract on enzymatic activities in diabetic rats. J. Appl. Sci. Res. 2012, 8, 10-16.

10. Al-Snafi, A.E.; Majid, W.J.; Ali Talab, T. Medicinal Plants with Antidiabetic Effects - An Overview (Part 1). IOSR Journal Of Pharmacy 2019, 9, 09-46

11. Verspohl, E.J.; Bauer, K.; Neddermann, E. Antidiabetic effect of Cinnamomum cassia and Cinnamomum zeylanicum in vivo and in vitro. Phytotherapy Research 2005, 19, 203-206, https://doi.org/10.1002/ptr.1643.

12. Jayaprasad, B.; Thamayandhi, D.; Shara Vanan, P.S. Traditionally using antidiabetic medicinal plants in tamil nadu. International Journal of Research in Pharmaceutical and Biosciences 2012, 2, 1-8.

13. Pathak, N.L.; Kasture, S.B.; Bhatt, N.M.; Rathod, J.D. Phytopharmacological properties of Coriander sativum as a potential medinal tree: an overview. Journal of Applied Pharmaceutical Science 2011, 1, 2025.

14. Ahmed, A.M.; Khabour, O.F.; Awadalla, A.H.; Waggiallah, H.A. Serum trace elements in insulin-dependent and non-insulin-dependent diabetes: a comparative study. Diabetes, Metabolic Syndrome and Obesity: Targets and Therapy 2018, 11, 887-892, https://doi.org/10.2147/DMSO.S186602.

15. Chen, M.D.; Lin, P.Y.; Tsou, C.T.; Wang, J.J.; Lin, W.H. Selected metals status in patients with noninsulindependent diabetes mellitus. Biol Trace Elem Res 1995, 50, 119-124, https://doi.org/10.1007/BF02789414.

16. Piero, N.M.; Njagi, J.M.; Kibiti, C.M.; Ngeranwa, J.J.N.; Njagi, E.N.M.; Miriti, P.M. The Role of Vitamins and Mineral Elements in Management of Type 2 Diabetes Mellitus: A Review. South As. J. Biol.Sci 2012, $2,107-115$

17. Rajalakshmy P. Role of Micronutrients on Type II Diabetes Mellitus. Acta Scientific Nutritional Health 2019, 3, 44-47, https://doi.org/10.31080/ASNH.2019.03.0444.

18. Zhou, Q.; Guo, W.; Jia, Y.; Xu, J. Comparison of Chromium and Iron Distribution in Serum and Urine among Healthy People and Prediabetes and Diabetes Patients. BioMed Research International 2019, 2019, https://doi.org/10.1155/2019/3801639.

19. Staniek, H. The Combined Effects of Cr(III) Supplementation and Iron Deficiency on the Copper and Zinc Status in Wistar Rats. Biological Trace Element Research 2019, 190, 414-424, https://doi.org/10.1007/s12011-018-1568-7.

20. Sanjeevi, N.; Freeland-Graves, J.; Beretvas, S.N.; Sachdev, P.K. Trace element status in type 2 diabetes: A meta-analysis. J Clin Diagn Res 2018, 12, OE01-OE08, https://doi.org/10.7860/JCDR/2018/35026.11541.

21. Rafi, M.; Laxmi Narayana, S. A study of chromium levels in type 2 diabetes mellitus. International Journal of Medical and Health Research 2019, 5, 126-130

22. Narendhirakannan, R.T.; Subramanian, S.; Kandaswamy, M. Mineral cintent of some medicinal plants used in the treatment of diabetes mellitus. Biol Trace Elem Res 2005, 103, 109-115, https://doi.org/10.1385/BTER:103:2:109.

23. Jung, M.; Park, M.; Lee, H.C.; Kang, Y.H.; Kang, E.S.; Kim, S.K. Antidiabetic agents from medicinal plants. Curr Med Chem 2006, 13, 1203-1218, https://doi.org/10.2174/092986706776360860. 
24. Gupta, J.; Gupta, A. Determination of trace metals in the leaves of Rauwolfia serpentina by using atomic absorption spectroscopy. IJCS 2016, 4, 94-96

25. Yasmin Khan, K.; Ajab Khan, M.; Niamat, R.; Munir, M.; Fazal, H.; Mazari, P.; Seema, N.; Bashir, T.; Kanwal, A.; Nisar Ahmad, S. Element content analysis of plants of genus Ficus using atomic absorption spectrometer. Afr. J Pharm. Pharmacol 2011, 5, 317-321.

26. Kazi, T.G.; Afridi, H.I.; Kazi, N.; Jamali, M.K.; Arian, M.B.; Jalbani, N.; Kandhro, G.A. Copper, Chromium, Magnese, Iron, Nickel, and Zinc levels in biological samles of diabetes mellitus patients. Biol Trace Elem Res 2008, 122, 1-18, https://doi.org/10.1007/s12011-007-8062-y.

27. Jiang, R.; Manson, J.E.; Meigs, J.B. Body iron stores in relation to risk of type-2 diabetes in apparently healthy women. JAMA 2004, 291, 711-717, https://doi.org/10.1001/jama.291.6.711.

28. Harati, M.; Ani, M.; Messeripour, M. Effect of Vanadyl sulphate on fructose-induced insulin resistance rat. Iranian Biomedical Journal 2003, 7, 179-182.

29. El-Demerdash, F.M.; Yousef, M.I.; Abou El-Naga, N.I. Biochemical study on hypoglycemic effects of onion and garlic in alloxan-induced diabetic rats. Food and Chemical Toxicology 2005, 43, 57-63, https://doi.org/10.1016/j.fct.2004.08.012. 